\title{
Survival of spores of the oyster pathogen Marteilia sydneyi (Protozoa, Paramyxea) as assessed using fluorogenic dyes
}

\author{
S. J. Wesche ${ }^{1, *}$, R. D. Adlard ${ }^{2}$, R. J. G. Lester ${ }^{1}$ \\ ${ }^{1}$ Department of Parasitology, The University of Queensland, Brisbane 4072, Australia \\ ${ }^{2}$ Protozoa Section, Queensland Museum, PO Box 3300, South Brisbane Q4101, Australia
}

\begin{abstract}
Sporonts of the paramyxean protist Marteilia sydneyi, aetiological agent of ' $Q X$ ' disease in the Sydney rock oyster Saccostrea commercialis, were isolated from infected oysters and maintained under various physical conditions to assess their survival. Survival was determined using 2 fluorogenic dyes, propidium iodide and 4',6-diamidino-2-phenylindole. The effects of salinity, temperature, ingestion by natural oyster predators, freezing and chlorination were examined. Dye exclusion indicated that spores were short-lived once isolated from the oyster, with the majority dead within 7 to $9 \mathrm{~d}$. Maximum longevity recorded was $35 \mathrm{~d}$ at $15^{\circ} \mathrm{C}$ and $34 \mathrm{ppt}$. Experiments to investigate the effects of ingestion by fish and birds revealed that spores did not survive for more than $2 \mathrm{~h}$ under these conditions, suggesting that it is unlikely that fish or birds play a significant role in the life cycle or dispersal of this parasite. Spores apparently remained viable for over 7 mo when frozen at -20 and $-70^{\circ} \mathrm{C}$. Chlorine treatments of $200 \mathrm{ppm}$ killed $99.5 \%$ of spores within $2 \mathrm{~h}$ and all spores within $4 \mathrm{~h}$ of exposure.
\end{abstract}

KEY WORDS: Viability Marteilia sydneyi Propidium iodide 4 4,6-diamidino-2-phenylindole QX Saccostrea commercialis . Fluorogenic dyes

\section{INTRODUCTION}

Marteilia sydneyi Perkins \& Wolf 1976, a paramyxean protozoan, is one of the most significant pathogens of the Sydney rock oyster Saccostrea commercialis. It causes ' $Q X$ ' disease, which is responsible for summer and autumn mortalities on commercial oyster leases from the Great Sandy Strait of southern Queensland $\left(25^{\circ} 30^{\prime} \mathrm{S}\right)$ to the Georges River in central New South Wales (34으) Australia (Nell \& Smith 1988, Adlard \& Ernst 1995). Attempts to control the disease have met with limited success. The only methods used have been husbandry techniques such as raising the growing height of oyster trays to reduce exposure time and the removal of commercial stock from estuaries and bays endemic to the disease during the usual infection period of January to April.

The earliest stage of Marteilia sydneyi as proposed by Perkins (1988) is a 2-celled plasmodium found in

\footnotetext{
•E-mail: s.wesche@mailbox.uq.edu.au
}

the hepatopancreas, in and between hepatopancreatic cells, and in connective tissue surrounding hepatopancreatic tubules of the Saccostrea commercialis. The parasite then undergoes sporulation to form either 8 or 16 sporonts by internal cleavage. Within each sporont, spore primordia divide internally to form 2 (rarely 3 ) spores. Each spore contains 3 concentric cells while refringent granules form within the sporont cytoplasm (Perkins \& Wolf 1976). At this stage, observation of wet smears of the digestive gland under a compound microscope reveals millions of sporonts within the tissue of heavily infected oysters, giving a rapid method of diagnosis.

The majority of sporonts are shed intact into the water, from the oyster, prior to the death of its host (Roubal et al. 1989). From this stage forward, the life cycle is unknown, as is the case with all members of the Paramyxea. Before additional and more effective control measures for this disease can be determined, a better knowledge of the development of the parasite is essential, especially for the period between release of 
sporonts in autumn to the onset of a new infection the following summer. To find clues to the life cycle of these organisms more information is required on the biology of the sporonts and spores once released into the environment. This study was designed to determine the survival of spores in vitro within the sporonts, once the sporonts had been isolated from their oyster host.

To determine their viability, spores were stained with 2 fluorogenic dyes, 4',6-diamidino-2-phenylindole (DAPI) and propidium iodide (PI). Evaluation of viability through inclusion and exclusion of fluorescent stains has proven successful on a wide variety of organisms including bacteria (Porter et al. 1997), mammalian and plant cells (Berglund et al. 1987, Sasaki et al. 1987), insect epithelial cells (Braun \& Keddie 1997), and parasitic protozoa such as Giardia muris (Schupp \& Erlandsen 1987a,b, Schupp et al. 1988) and Cryptosporidium parvum (Campbell et al. 1992, Robertson et al. 1992, Anguish \& Ghiorse 1997).

\section{MATERIALS AND METHODS}

Oysters infected with Marteilia sydneyi were collected from the Pimpama River $\left(27^{\circ} 49^{\prime} 50^{\prime \prime} \mathrm{E}, 153^{\circ} 23^{\prime} 75^{\prime \prime} \mathrm{S}\right.$ ), a known endemic area. The digestive gland of heavily infected oysters was excised and placed in $20 \mathrm{ml}$ of artificial seawater (Aquasonics Australia, $30 \mathrm{ppt}$ ) with
2 drops of Tween 80 (to prevent clumping of cells), and homogenised (Ultra Turrax T25 homogeniser). Homogenates were not purified because preliminary tests showed that spore viability was reduced significantly when sucrose gradients were used to separate the sporonts from remaining oyster tissue. Fresh homogenates were made for each treatment (salinity, temperature, digestion, freezing and chlorination). Three samples were used for each treatment, each using separate homogenates from 3 infected oysters, in an attempt to reduce the variability of spore viability between oysters. Samples of all homogenates were stained with the fluorescent dyes immediately before the commencement of each treatment to assess initial spore viability.

Working solutions of DAPI (2 $\mathrm{mg} \mathrm{ml}^{-1}$ in absolute methanol) and PI (1 $\mathrm{mg} \mathrm{ml}^{-1}$ in $0.1 \mathrm{MPBS}, \mathrm{pH} 7.2$ ) were prepared and stored at $4^{\circ} \mathrm{C}$ in the dark. Ten microlitres of each working solution was added to $100 \mu \mathrm{l}$ of each homogenate and incubated for $1 h_{\text {; }}$ the solutions were then centrifuged and washed twice in artificial seawater before being examined microscopically (Campbell et al. 1992).

Ten microlitre aliquots of each stained homogenate viewed under a microscope using epifluorescence with a Nikon EFD-3 microscope attachment equipped with a UV filter block for DAPI and a green filter block for PI. Sporonts containing spores which were DAPI-posi-
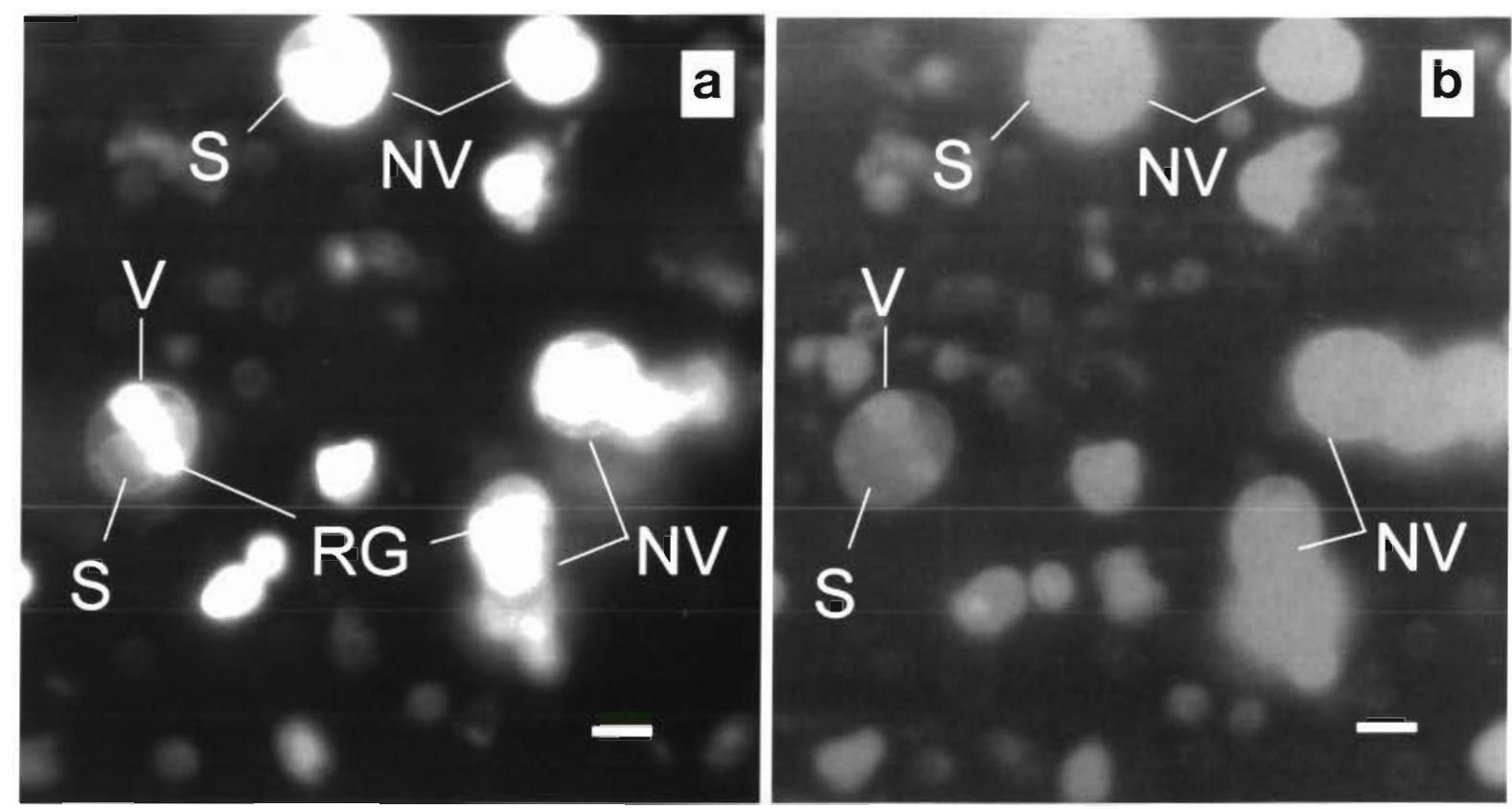

Fig. 1. Sporont homogenate stained with DAPI and PI and viewed through (a) a UV filter block and (b) a green filter block. A single sporont containing viable spores (V) is shown with 4 sporonts containing non-viable spores (NV). Note fluorescence of the spores (S) of a viable sporont in (a). The same spores (S) in (b) show no PI fluorescence when viewed with the green filter block, while non-viable spores (NV) fluoresce to the extent that the internal structure of the sporont is obscured. The refringent granules (RG), due to their refractile nature, fluoresce regardless of spore viability. Scale bar $=10 \mu \mathrm{m}$ 
tive PI-negative were considered viable (see Fig. 1), while sporonts with spores staining PI-positive were considered non-viable. In some sporonts only 1 spore was visible due to its orientation on the slide. In this case, if the single visible spore was PI-positive, both spores within the sporont were considered non-viable. Results were cuantified by evaluating the viability of 300 intact sporonts in each sample (3 samples for each treatment, $N=900$ sporonts total). Ruptured sporonts were considered to be an artifact of homogenisation and were ignored.

Preliminary tests showed that the viability of spores at the time of :elease from the oyster was high 90 to $100 \%$ ), if the oyster was in good condition. In weak oysters the decline in condition was matched by a decline in the viability of spores. Most spores from dead or moribund oysters stained non-viable (authors' pers. obs.). In this study, we used spores removed from oysters which showed no gross signs of disease to maximise potential spore survival and provide conservative estimates of death rates.

To test salinity tolerance, $2 \mathrm{ml}$ of homogenate was added to 5 containers of artificial seawater $(25 \mathrm{ml})$ with salinities of $0,10,20,30$, and $40 \mathrm{ppt}$, respectively, and maintained at $25^{\circ} \mathrm{C}$. The sporonts settled to the bottom within a few minutes. The supernatant (free of sporonts) in each container was changed every $24 \mathrm{~h}$, to reduce bacterial build up within the containers (in this and in all following treatments). This process had been shown previously to have no effect on spore survival. The viability of the spores was assessed after $24 \mathrm{~h}$, and then at $48 \mathrm{~h}$ intervals until all spores stained nonviable. The volume of sporont solution used in each microscopic assessment of viability (for this and all treatments) was $0.37 \%$ of the total homogenate volume for each treatment and considered to have a negligible impact on subsequent microscopic assessments.

Temperature tolerance was assessed by adding $2 \mathrm{ml}$ of homogenate to 6 containers of artificial seawater (25 ml, $34 \mathrm{ppt}$ ) and kept at $4,15,25,29,37$ and $60^{\circ} \mathrm{C}$, respectively. The viability of the spores was assessed after $24 \mathrm{~h}$, and then at $48 \mathrm{~h}$ intervals until all spores were assessed as non-viable

To examine the effect of freezing, $1 \mathrm{ml}$ of each homogenate was alloquoted into a $1.5 \mathrm{ml}$ tube and placed in a freezer at -20 or $-70^{\circ} \mathrm{C}$. After $24 \mathrm{~h}, 7 \mathrm{~d}$, $30 \mathrm{~d}$ and $220 \mathrm{~d}$ the homogenate was thawed and the viability of the spores tested.

Homogenates were added to 3 containers of chlorinated artificial seawater $(25 \mathrm{ml}$ volume, $34 \mathrm{ppt}$ salinity, available chlorine from granular calcium hypochlorite $650 \mathrm{~g} \mathrm{~kg}^{-1}$ ) then kept in the dark to minimise chlorine loss. Free chlorine concentrations were 50, 100 and 200 ppm, respectively. The viability of the spores within each homogenate was assessed after 2 and $4 \mathrm{~h}$.
Yellowfin bream Acanthopagrus australis are a natural predator of oysters and have been implicated by many oyster farmers as a dispersal mechanism for QX disease. Therefore 4 bream, 8 to $17 \mathrm{~cm}$ in length, were fed pieces of infected oyster tissue and allowed to digest for up to $20 \mathrm{~h}$. The fish were then euthanased by anaesthetic overdose and their digestive tract removed. The tract was divided into stomach, upper intestine and lower intestine by ligation and the contents removed and stained immediately with vital dyes to assess the viability of the spores.

To simulate avian digestion, homogenates were placed in a pepsin digestive solution $(0.5 \mathrm{~g}$ pepsin, $0.75 \mathrm{ml} \mathrm{35 \%} \mathrm{HCl}, 100 \mathrm{ml} 0.6 \% \mathrm{NaCl}$ ), as used by Erasmus (1962) on a cavity slide at $37^{\circ} \mathrm{C}$. Homogenates were monitored under a compound microscope for periods of up to $2 \mathrm{~h}$.

Where stated, results were tested for significance using binary logistic regressions within the software package Minitab. Results were considered to be significant where $\mathrm{p} \leq 0.05$.

\section{RESULTS}

In the salinity tests, spores became $100 \%$ non-viable by Day 9 in salinities of 30 and 40 ppt (Fig. 2). In 10 and 20 ppt spores stained non-viable by Day 3 while at 0 ppt all spores were non-viable after 24 h (Fig. 2). Even though the 10 and 20 ppt group of data (and the 30 and 40 ppt group of data) showed similarities in survivorship, analysis of results did indicate significant differences in survival rates over time. No changes in the morphology of either the spores or sporonts indicative of further development were observed during the treatments.

In general, an increase in spore viability was observed with decrease in temperature (Fig. 3). An exception occurred with the $4^{\circ} \mathrm{C}$ treatment after $5 \mathrm{~d}$, in which spore survival was less than at $15^{\circ} \mathrm{C}$. Maximum survival of spores of $33 \mathrm{~d}$ was obtained in the $15^{\circ} \mathrm{C}$ treatment. At the highest temperature $\left(60^{\circ} \mathrm{C}\right)$ all spores

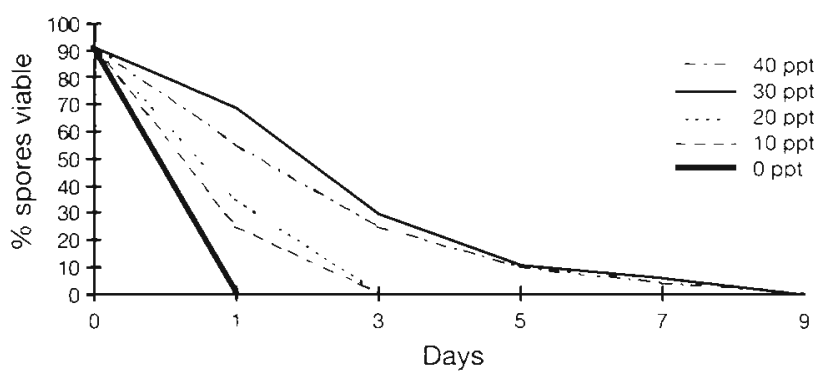

Fig. 2. Viability of $Q X$ spores over time exposed to different salinities $(0,10,20,30$ and $40 \mathrm{ppt})$ 


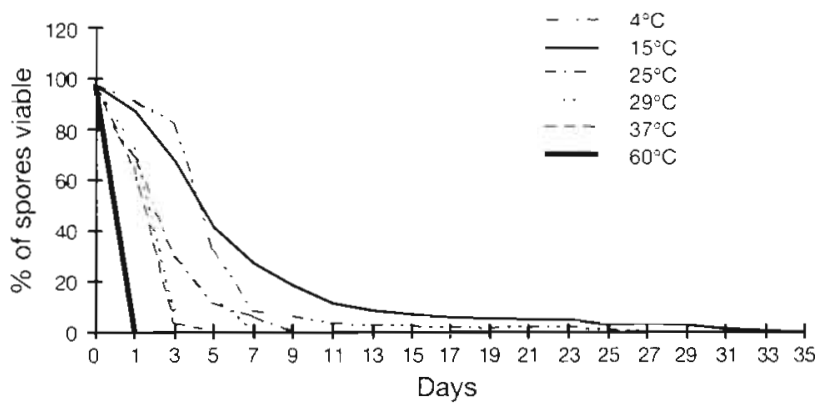

Fig. 3. Viability of $Q X$ spores maintained at different temperatures over time $\left(4,15,25,29,37\right.$ and $\left.60^{\circ} \mathrm{C}\right)$

were non-viable by $24 \mathrm{~h}$ post-treatment. Analysis of the results showed that each treatment had significantly different survival rates. The majority of spores in all treatments were non-viable after 7 to $9 \mathrm{~d}$ though a few sporonts treated at 4 and $15^{\circ} \mathrm{C}$ survived for 27 and $35 \mathrm{~d}$, respectively. After $11 \mathrm{~d}$ at $15^{\circ} \mathrm{C}$, viable spores free of their sporonts were observed within the homogenate. The sporont walls appeared to have decomposed. Free spores were usually seen in pairs although, rarely, single viabie spores were observed. Some free spores were observed in the $4^{\circ} \mathrm{C}$ treatment after $21 \mathrm{~d}$; however, they were rare in comparison to the $15^{\circ} \mathrm{C}$ treatment, and appeared only a few days before the eventual death of all spores at $4^{\circ} \mathrm{C}$. Free spores were not observed in any other treatment.

At -20 and $-70^{\circ} \mathrm{C}$ spore survival was reduced to 5.8 and $3.5 \%$, respectively, after a period of $220 \mathrm{~d}$ frozen (Fig. 4), although most spores stained non-viable after $7 \mathrm{~d}$. There was no significant difference in the survival of spores between the 2 treatments.

After $2 \mathrm{~h}$ in 200 ppm chlorine, $0.5 \%$ of spores stained viable, with all spores dead $4 \mathrm{~h}$ post-treatment. The other 2 treatments (50 and $100 \mathrm{ppm}$ ) showed significantly increased survival rates compared to the 200 ppm treatment (see Fig. 5).

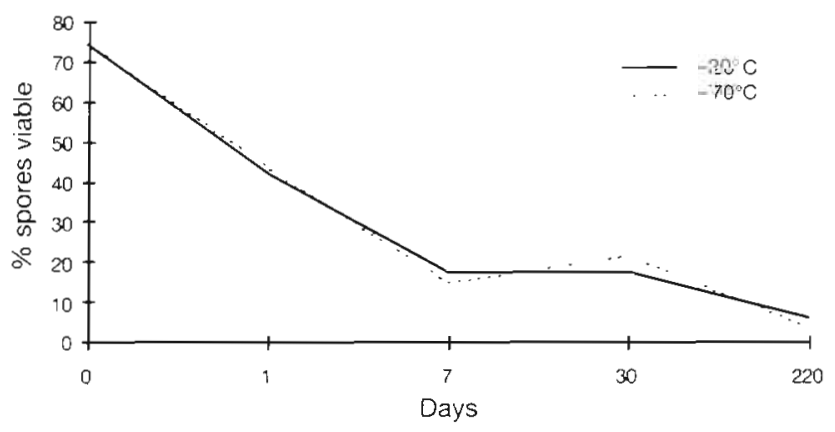

Fig. 4. Viability of QX spores over time, after being frozen at -20 and $-70^{\circ} \mathrm{C}$

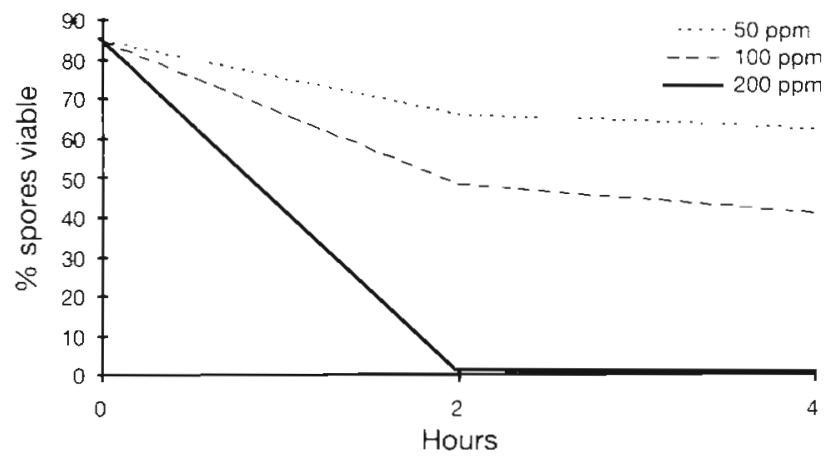

Fig. 5. Viability of $Q X$ spores over time after exposure to different concentrations of chlorine $(50,100$ and $200 \mathrm{ppm})$

Sporonts fed to fish in oyster tissue were isolated from the stomach and the upper intestine of all 4 yellowfin bream, but only 1 of the 4 fish had recognisable sporonts in the lower intestine. Two fish had large numbers of non-viable spores in the stomach (>1000 spores) and upper intestine (>100 spores). The lower intestine of those fish without recognisable spores contained digested cellular material, presumably of oyster and Marteilia sydneyi origin. No viable spores were observed in the digestive tract of any of the 4 bream examined.

After $2 \mathrm{~h}$ in the pepsin solution no sporonts were visible within the homogenates. All recognisable spores were in advanced stages of degradation.

\section{DISCUSSION}

Outbreaks of Marteilia sydneyi occur annually during the southern hemisphere summer between the months of January and April. The majority of infected oysters shed their sporonts and die 6 to $8 \mathrm{wk}$ after infection. The time between the release of spores (within sporonts) and the appearance of a new infection the following season may be as long as 8 to $12 \mathrm{mo}$, during which time the location of spores is unknown. Previous hypotheses have suggested that spores undergo either a period of maturation in the environment or a period of development in an intermediate host, prior to infecting oysters during the following summer (Grizel 1985, Lester 1986, Perkins 1988).

The results from the salinity and temperature experiments show that the majority of spores die after 7 to $9 \mathrm{~d}$. Maximum survival (35 d) was reached by a small proportion of spores kept at $15^{\circ} \mathrm{C}$ and $34 \mathrm{ppt}$ salinity. No morphological changes to either the spores or the sporonts were observed during these experiments apart from those associated with the natural degradation of the cells. 
Since (1) the spores are relatively short-lived ( 7 to $35 \mathrm{~d})$ in comparison to infection cycles in the oyster (10 to $12 \mathrm{mo}$ ), (2) there is no evidence of morphological changes leading to further development outside the oyster, and (3) no known energy reserve within the sporont (Roubal et al. 1989), it appears that spores do not mature in the environment. Experimental evidence in this study as well as that of Grizel (1985), Lester (1986), Lester \& Healy (1986), Perkins (1988), and Roubal et al. (1989) infers consistently the need for an intermediate host that actively takes up the non-motile spores shortly after they are shed from the oyster.

For many years fish and birds that feed on oysters have been the subject of industry concern not only as potential hosts for the disease but as vectors of dispersal, along with the industry practice of moving live oysters between leases in different estuaries. The feeding experiments carried out on the yellowfin bream (a natural predator of oysters) showed conclusively that the spores do not survive the digestive processes of these fish and it is therefore unlikely that fish are a host or transport mechanism for the disease. Spores were observed along all stages of their digestive tracts with no viable cells isolated. Similarly, pepsin treatments that simulated avian digestion show that spores would not survive in the gut of birds. Total cellular destruction was observed after $2 \mathrm{~h}$ in the pepsin digestive solution. Similar experiments were carried out by Lester \& Healy (1986) when they fed tiger mullet Liza argentea spores of Marteilia sydneyi and found structural changes to the spore membrane, and concluded that spores do not survive long in the gut of this fish. However, they had difficulty identifying spores within the digestive tract (Lester pers. comm.). The staining procedure used here not only made the spores highly visible but also indicated their viability.

The pathogenicity of Marteilia sydneyi, and its status as a List B organism with the Office Internationale des Epizooties (OIE), prompted our investigation into quarantine and sterilisation methods. A sterilisation treatment must be $100 \%$ effective in killing the spores, must be rapid, must be inexpensive, and must have no associated deleterious effects on the environment. Given these parameters, the results from the freezing trials showed little potential as a control method since viable spores were still observed in all tested homogenates even after 7 mo. The chlorine trials showed greater potential, with $99.5 \%$ of spores rendered nonviable after $2 \mathrm{~h}$ at $200 \mathrm{ppm}$ chlorine and total death of spores after $4 \mathrm{~h}$. This treatment becomes significant for M. sydneyi control, because in New South Wales all oysters are required to undergo a period of depuration, in which oysters are held in tanks (ranging in size from 2000 to $10000 \mathrm{l}$ capacity) for $36 \mathrm{~h}$ (Ayres 1991) prior to sale for human consumption. In a typical depuration system water is pumped from the estuary into tanks, oysters are placed in the tanks for the required period (at controlled temperature and salinity), oysters are removed and depuration water released back into the estuary. This only becomes a problem when oysters from a QX-endemic estuary are transported to a depuration system located on a QX-free estuary. It is at this point that depuration water requires sterilisation prior to release, to remove the potential for contamination of the estuary.

In conclusion, these results demonstrate that, once shed from the oyster, spores of Marteilia sydneyi are short-lived. The presence of an intermediate host in the life cycle is implied strongly, while native fish and birds are unlikely to play a role as potential hosts or dispersal mechanisms for this disease. Chlorine treatments at $200 \mathrm{ppm}$ may prove to be a practical and useful tool to sterilise closed systems and reduce potential for transfer of $M$. sydneyi between endemic and QX-free estuaries.

\section{LITERATURE CITED}

Adlard RD, Ernst I (1995) Extended range of the oyster pathogen Marteilia sydneyj. Bull Eur Assoc Fish Pathol 15(4):119-121

Anguish LJ, Ghiorse WC (1997) Computer-assisted laser scanning and video microscopy for analysis of Cryptosporidium parvum oocysts in soil, sediment, and feces. Appl Environ Microbiol 63(2):724-733

Ayres PA (1991) The status of shellfish depuration in Australia and southeast Asia. In: Otwell WS, Rodrick GE, Martin RE (eds) Molluscan shellfish depuration. CRC Press, Boca Raton, FL, p $287-321$

Berglund DL, Taffs RE, Robertson NP (1987) A rapid analytical technique for flow cytometric analysis of cell viability using calcofluor white M2R. Cytometry 8:421-426

Braun L, Keddie BA (1997) A new tissue technique for evaluating effects of Bacillus thuringiensis toxins on insect midgut epithelium. J Invertebr Pathol 69:92-104

Campbell AT, Robertson LJ, Smith HV (1992) Viability of Cryptosporidium parvum oocysts: correlation of in vitro excystation with inclusion or exclusion of flurogenic vital dyes. Appl Environ Microbiol 58(11):3488-3493

Erasmus DA (1962) Studies on the adult and metacercaria of Holostephanus liihei Szidat 1936. Parasitology 52:353-374

Grizel H (1985) Etude des recentes épizooties de l'huittre plate Ostrea edulis Linné et de leur impact sur l'osteiculture Bretonne. Thèse, Académie de Montpellier, Université des Sciences et Techniques du Languedoc

Lester RJG (1986) Field and laboratory observations on the oyster parasite Marteilia sydneyi. In: Cremin M, Dobson C. Moorhouse D (eds) Parasite lives. University of Queensland Press, Brisbane, p 33-40

Lester RJG, Healy JM (1986) Possible ultrastructural evidence for a fish alternate host in the lifecycle of the oyster pathogen Marteilia sydneyi (Protozoa, Ascetospora). Abstract. International Congress of Parasitology VI. Australia Academy of Science, Canberra, p 176

Nell JA, Smith IR (1988) Management, production and disease interactions in oyster culture. In: Bryden DI (ed) Fish 
disease. Postgraduate Committee in Veterinary Science, University of Sydney, Sydney, New South Wales, p 127-133

Perkins FO (1988) Structure of protistan parasites found in bivalve molluscs. In: Fisher W (ed) Disease processes in marine bivalve molluscs. Am Fish Soc, Spec Publ 18, p 93-111

Perkins FO, Wolf PH (1976) Fine structure of Marteilia sydneyi sp. n.-haplosporidian pathogen of Australian oysters. J Parasitol 62:528-538

Porter J, Pickup P, Edwards C (1997) Evaluation of flow cytometric methods for the detection and viability assessment of bacteria from soil. Soil Biol Biochem 29(1):91-100

Robertson LJ, Campbell AT, Smith HV (1992) Survival of Cryptosporidium parvum aocysts under various environmental presures. Appl Environ Microbiol 58(11):3494-3500

Roubal FR, Maisal J, Lester RJG (1989) Studies on Marteilia sydneyi, agent of QX disease in the Sydney rock oyster,

Editorial responsibility: Albert Sparks,

Seattle, Washington, USA
Saccostrea commercialis, with implications for its life cycle. Aust J Mar Freshw Res 40:155-167

Sasaki DT, Dumas SE, Engleman EG (1987) Discrimination of viable and non-viable cells using propidum iodide in two color immunofluorescence. Cytometry 8:413-420

Schupp DG, Erlandsen SL (1987a) A new method to determine Giardia cyst viability: correlation of fluorescein diacetate and propidium iodide staining with animal infectivity. Appl Environ Microbiol 53(4):704-707

Schupp DG, Erlandsen SL (1987b) Determination of Giardia munis cyst viability by differential interference contrast, phase, or brightfield microscopy. J Parasitol 73(4):723-729

Schupp DG, Januschka MM, Sherlock LF, Stibbs HH, Meyer EA, Bemrick WJ, Erlandsen SL (1988) Production of viable Giardia cysts in vitro: determination by flurogenic dye staining, excystation, and animal infectivity in the mouse and Mongolian gerbil. Gastroenterology 95:1-10

Submitted: May 18, 1998; Accepted:December 14, 1998

Proofs received from author(s): May 17, 1999 